\title{
Changing marriage system of Adivasi Garo Community and its impact on their socioeconomic development
}

\author{
K. Ahmed, R. N. Ali and F. Begum \\ Department of Rural Sociology, Bangladesh Agricultural University, Mymensingh-2202, Bangladesh
}

\begin{abstract}
The purpose of the study was to analyze the changing pattern of marriage system of Adivasi Garo community. For the study, Modhupur upazila of Tangail district for Plain Garos and Haluaghat upazila of Mymensingh district for Hill Garos were chosen as the research areas. From these two upazila, six villages were selected randomly for collecting sample population. The sample consisted of 100 , taking 50 Hilly Garo respondents from three villages of Haluaghat upazila and 50 Plain Garo respondents from three villages of Modhupur upazila. Primary data were collected from the respondents through a sample survey with the help of a interview schedule. It was found that in both upazila, the essential rules for their marriage were maintained but due to conversion of Christianity, these rules are changing. $A$ rule followed by the respondents is highest in case of a Garo should always marry a Garo (95\%). Christian marriage rituals are now increasing in both upazila. Very few traditional rituals were followed by Garos for establishing their marriage. Before conversion to Christian, Garos were used to the traditional forms of marriage such as 'Marriage by Capture' and Thunapp' a marriage (marriage through food offering) which has stopped now but still today it has some influences upon their marriage system. The study also revealed that most of the Garos are interested in love marriage and arranged marriage. In love marriage, Garos select their life partners themselves. After marriage, today the male Garos are not interested in moving to his wife's parents house; rather they are living in a independent house. Moreover, while the Garo society is changing from a matrilineal to patriarchal one, this change invites many changes in their social and cultural life, such as inheritance, gender roles, post marital residence etc. The finding also showed that despite many similarities, there are very few customs and ritualistic differences between two upazilas, but comparatively Hilly Garo villages culture and tradition were changing less than the plain Garo villages.
\end{abstract}

Keywords: Garo community, Hilly Garo, Plain Garo, Marriage system, Changing rules

\section{Introduction}

The word Adivasi is used for the Indigenous/Minority people in Bangladesh. In Bangladesh there are 45 indigenous groups, approximately 1.2 million and $1.13 \%$ of the total population (BBS, 2001). Among them the Garo is one of the largest indigenous communities of Bangladesh. They live in the north-eastern parts of the country especially in Gazipur, Mymensingh, Netrokona, Tangail, Sheerpur, Jamalpur and some in Sylhet district close to the Indian border. Their present population around the world is approximately half a million, of them about one-fifth of the total population of the Garos lives in Bangladesh (Chowdhury, 2007). Garos are mostly known to the outside world for their matrilineal social organization especially for their distinct kinship system (Burling, 1997). The people who are known as Garo to outsides prefer to call themselves Mandis (Bleie, 2005). Garos are a distinct ethnic community who also prefer to call themselves Achik. Garos have their own language, which is called Achchik Katha. Like any other indigenous group Garos also have their own dress. In the past, Garo used to put on the barks of trees. Traditionally the common dress of Garo males is Jana or Nengti, but now educated Garo males also wear lungi, short shirts, pants, etc. The women cover their breast by knotting a piece of short cloth on their backs, but now they put on sari and kamiz instead of their traditional skirts (Banglapedia, 2006). The traditional Garo religion is Sangsharek, which is almost abolished and practiced by very few Garo people in some areas). A Garo male should marry between the age 25 to 30 years and female 20 to 25 years. Due to matrilineality, every Garo belongs to his or her mother's lineage and takes the mother's family name. According to the Garo's inheritance system, men do not inherit property from the parents; all go to the women (Chowdhury, 2007). Their residence pattern is matrilocal, the husband moves to the wife's house after marriage. The traditional Garo society is changing widely; it has accepted and absorbed many traits from others communities which have greater influence on their traditional marriage system. 
There are many factors responsible for Garo's cultural changes such as Christianity, formal education, modernization, occupational diversification, Bengali settlement, migration to the city for work and income, influence of national culture, influence of the media, TV, radio, film etc. Almost all the Garos are now Christian. Christianity has influenced and changed the Garos a lot. Christianity does not allow the traditional practices. Christianity insisted the Garo people for new beliefs that separate them from the Sangsharek beliefs and practices (Thunapp' a marriage, marriage by capture). Now they do not practice their old marriage system, Christian laws of marriage substitute them.

Various studies were undertaken in various times by different researchers throughout the world regarding socioeconomic condition, marriage system, health status of the Garo community. Burling (1997) in his study examined that Garos are mostly known to the outside world for their distinct matrilineal social organization especially for their distinct kinship system. The small material objects of daily life are no longer different from those of their Bengali neighbours because day-to-day contact with Bengali people they have been much more influenced and changed in their food habits, dress, songs, language, and behaviour, and even in their housing pattern. Partha (2003) conducted a study on bio-diversity of Modhupur Tract which identified some problems of the Garos in relation to agricultural activities. These are irrigation problem, high cost of irrigation fuel, damage of crops by cattle, deforestation and increasing inhabitation of outsiders in the Garo community. Bal (2000) observed that over the years, most of the Garos have been converted to Christian and a few into Muslim. Christianity has a major impact on their socioeconomic, psychological, cultural and political situation. Similar findings are available from developed countries that are mostly general type. But, similar kind of research finding is not yet available in Bangladesh context. Therefore, a study was designed to determine the changing patterns of marriage system of Adivasi Garo community. The specific objectives of the study were i) to examine the rituals and steps observed for establishing Garo marriage and ii) to analyze the comparative changes in the Garo marriage between the Garo living in the Modhupur(Plain Garo) and Haluaghat (Hilly Garo).

\section{Materials and Methods}

Six villages, namely, Edilpur of Aousnara union, Talki of Orunkhola union, Chunia of Sholakori union under Modhupur upazila of Tangail district and Corbangalia of Gajirvita union, Biroidakong of Haluaghat union, komoria of Norail union under Haluaghat upazila of Mymensingh district were selected for the study. The target population of the study was the Garos who were living in these six villages. A sample of 100 respondents, 50 from Modhupur upazila of Tangail district and 50 from Haluaghat upazila of Mymensingh district was chosen randomly in order to meet the objectives of the study. In this study, both quantitative and qualitative methods were used. Quantitative method like survey method was chosen and qualitative method like participant observation, informal interviewing were used. The data were collected during the period from April to September, 2009. Primary data were collected personally from the respondents through a sample survey with the help of a structured and pre-tested interview schedule. The collected data were coded and analyzed using SPSS software in accordance with the objectives of the study. Tabular method was used for a substantial part of data analysis. Relatively simple statistical technique such as percentage was taken into account to analyze the data.

\section{Results and Discussion}

\section{Changes in the essential rules for Garo marriage}

Like other communities of the world, marriage is a significant event in the Garos social and cultural life. Marriage is almost universal among the Garo. According to Playfair (1998), in the theory, marriage is strictly exogamous among the Garos and the husband and wife must belong to different steps and motherhoods. The children invariably belong to the mother's step and motherhood. Great importance is attached to this rule, and those who break it, and marry within their own clan are considered to have committed a social sin .At the beginning of the last century, the pioneer Garo scholar Major Playfair has also observed that this exogamous rule of Garo marriage is changing, according to him; 'the inevitable rule of exogamy is changing. Marriage between a man and woman belong to the same clan is not 
uncommon. If there is marriage within the same clan, the couple is ridiculed as Bacdong (marriage between one's relative). In the past it was treated as an offence, and those couples were not allowed to stay in the village. With the passage of time, now community has accepted this derivation.

Table 1 shows that in both upazila the essential rules were maintained more or less. But these rules are changing due to the conversion of Christianity. A rule followed by the respondent is highest in case of a Garo should always marry a Garo (95\%) and the husband and wife must belong to different clans (81\%). In the study area Christian marriage rituals are increasing. In Haluaghat $76 \%$ respondent reported that they maintained the rules of the partner must be Christian and do not allow any Bengali Muslim and 24\% said that they choice traditional Garo. In Modhupur upazila 88\% respondent said that they maintained the rules of the partner must be Christian and do not allow any Bengali Muslim and only $12 \%$ respondent still now practice that the partner must be traditional Sangsharek Garo.

\section{Table 1. Perception of respondents regarding rules}

\begin{tabular}{|c|c|c|c|c|c|c|}
\hline \multirow{2}{*}{ Essential rules for Garo marriage } & \multicolumn{2}{|c|}{ Haluaghat } & \multicolumn{2}{|c|}{ Modhupur } & \multicolumn{2}{|c|}{ Total } \\
\hline & No. & $\%$ & No. & $\%$ & No. & $\%$ \\
\hline A Garo should always marry a Garo & 48 & 96 & 47 & 94 & 95 & 95 \\
\hline The husband and wife must belong to different clans & 44 & 88 & 41 & 82 & 85 & 81 \\
\hline The partner must be Christian & 38 & 76 & 44 & 88 & 82 & 82 \\
\hline The partner must be traditional Sangsharek Garo & 12 & 24 & 6 & 12 & 16 & 16 \\
\hline A Christian Garo must never marry Bengali Muslim & 31 & 62 & 38 & 76 & 69 & 69 \\
\hline $\begin{array}{l}\text { Marriage between a Bengali Muslim and a Christian } \\
\text { Garo will be turned out of Church }\end{array}$ & 38 & 76 & 44 & 88 & 82 & 82 \\
\hline
\end{tabular}

Source: Field Survey, 2009

Note: Percentage was calculated by using 50 for Haluaghat and the same for Modhupur and the total number of respondents is 100 .Some are multiple answers.

\section{Pattern of selection of partners}

In the Garo community the mode of selection differs from place to place. The most practiced forms of marriage among the Garos of Haluaghat and Modhupur are love marriage and arranged marriage. Among them the most popular type of Garo marriage is arranged marriage. This type of marriage is usually arranged by the parents with the help of a matchmaker. The matchmaker may be a friend or relative and can be of any parties. In Haluaghat $55 \%$ male and $56.67 \%$ female select the partner by arranged marriage, $30 \%$ male and 30\% female select the partner by love marriage, $5 \%$ male and $3.33 \%$ female have partner-fixed and 10\%male and $10 \%$ female select the partner by love and arranged marriage. In Modhupur 36.36\% male and 50\% female select the partner by arranged marriage, $45.46 \%$ male and $32.14 \%$ female select the partner by love marriage, $18.18 \%$ male and $17.86 \%$ female select the partner by love and arranged marriage and there are no partner-fixed in this upazila.

Table 2. Selection of partners in the Garo community

\begin{tabular}{|c|c|c|c|c|c|c|c|c|c|c|}
\hline \multirow[t]{3}{*}{ Types } & \multicolumn{4}{|c|}{ Haluaghat } & \multicolumn{4}{|c|}{ Modhupur } & \multirow{2}{*}{\multicolumn{2}{|c|}{ Total }} \\
\hline & \multicolumn{2}{|c|}{ Male } & \multicolumn{2}{|c|}{ Female } & \multicolumn{2}{|c|}{ Male } & \multicolumn{2}{|c|}{ Female } & & \\
\hline & No. & $\%$ & No. & $\%$ & No. & $\%$ & No. & $\%$ & No. & $\%$ \\
\hline Arranged marriage & 11 & 55 & 17 & 56.67 & 8 & 36.36 & 14 & 50 & 50 & 50 \\
\hline Love marriage & 6 & 30 & 9 & 30 & 10 & 45.46 & 9 & 32.14 & 34 & 34 \\
\hline Partner-fixed & 1 & 5 & 1 & 3.33 & 0 & 0 & 0 & 0 & 2 & 2 \\
\hline Love and arranged marriage & 2 & 10 & 3 & 10 & 4 & 18.18 & 5 & 17.86 & 14 & 14 \\
\hline Total & 20 & 100 & 30 & 100.00 & 22 & 100.00 & 28 & 100.00 & 100 & 100 \\
\hline
\end{tabular}

Source: Field Survey, 2009 


\section{Changing decision on marriage}

In the matriarchal societies, the mother is the first to be approached for the decision of marriage. However, 10 men and 18 women got the decision of both the parents but approached the mother through the father, only 4 men and 8 women got permission only of the mother and 6 men and 4 women got only that of the father in Haluaghat. On the contrary, 13 men and 16 women got the decision of both the parents but approached the father through the mother, Only 3 men and 4 women got permission only of the mother and 6 men and 8 women got only that of the father in Modhupur. It is one more sign that the matrilineal Garo society is moving slowly towards stronger patriarchy. Men are beginning to play the role of heads of families. Decision of marriage in the family is shown in Table 3.

Table 3. Decision regarding marriage

\begin{tabular}{|l|c|c|c|c|c|c|}
\hline \multirow{2}{*}{ Gender } & \multicolumn{3}{|c|}{ Haluaghat } & \multicolumn{3}{c|}{ Modhupur } \\
\cline { 2 - 7 } & Mother & Father & Both & Mother & Father & Both \\
\hline Male & 4 & 6 & 10 & 3 & 6 & 13 \\
\hline Female & 8 & 4 & 18 & 4 & 8 & 16 \\
\hline Total & 12 & 10 & 28 & 7 & 14 & 29 \\
\hline
\end{tabular}

Source: Field Survey, 2009

\section{The changing roles of village elders}

In the Garo tradition, a family referred the marriage plan to the council which in turn formally proposed to the girl's family. After it an elderly man blessed the couple and performed some rituals. However, the modern statutory village council has nothing to do with marriage as such. It was also seen that the Nokma (Husband of heiress daughter) administered justice according to their rules but played no role in marriage that they consider a family affair. Its arrangement is subjected to the will of the chra (most respected person in the Garo community) and the parents of the girl. It decides whom and when she is to marry. The decision of the chra and the mahari (only the most closely related person within the same machong) is final. Traditionally it negotiated and even formalized the marriage but the main decision even in that case was taken by the maharis. Apart from change of religion, education too has made a difference. A section of the Garo no longer forces their sisters and nieces to marry a widower. Thus, education and religion have changed the attitude of unquestioning acceptance of the tradition but in the process might have also given up the customs that conferred a higher status on women. The changing role of village elders in the Garo community is shown in Table 4.

Table 4 shows that the Council played no role in the marriage of 69 respondents but intervened in 31cases. In Haluaghat 4 male and 7 female said that village elder played as a middleman, the village council formalized the marriage of only 3 male and 2 female and only 1 female said that their roles as fixed bride price. In Modhupur upazila, 2 male and 5 female respondents said that village elder played as a middleman, the village council formalized the marriage of only 2 male and 2 female and only 1 male and 2 female said that their roles as fix bride price. Most of the Garo who have been converted to Christian exclude the village council completely. It is a major change caused by change of religion.

Table 4. Roles of village elders/council in decisions on Garo marriage

\begin{tabular}{|l|c|c|c|c|c|c|c|}
\hline \multirow{2}{*}{ Categories } & \multicolumn{2}{c|}{ Haluaghat } & \multicolumn{2}{c|}{ Modhupur } & \multicolumn{2}{c|}{ Total } & \multirow{2}{*}{ Total } \\
\cline { 2 - 8 } & Male & Female & Male & Female & Male & Female & \multicolumn{2}{c|}{69} \\
\hline No role & 13 & 20 & 17 & 19 & 30 & 39 & 12 \\
\hline Middleman & 4 & 7 & 2 & 5 & 6 & 3 & 4 \\
\hline Fix bride price & 0 & 1 & 1 & 2 & 1 & 5 & 9 \\
\hline Formalize/ Blessing & 3 & 2 & 2 & 2 & 5 & 4 & 58 \\
\hline Total & 20 & 30 & 22 & 28 & 42 & 100 \\
\hline
\end{tabular}

Source: Field Survey, 2009 


\section{The changing customs before marriage in the Garo community}

Among the Garo, after the solemn engagement between the two machongs (respected common mother of a group of people), the boy and girl are not allowed to go about freely or to live together before the formal marriage. As part of the etiquette in concluding the pre-marital contract the Garo bring presents such as a cock or a bull as symbol of co-operation between the two maharis. Many Garo customs and practices have changed after their Christianization but their core remains. Religious change has introduced another new element in the formal consent. Table 5 shows that 20 male and 24 female respondents follow church clearance for their marriage, 40 male and 58 female respondents said that until marriage no live together. The ban on living together is intrinsic to religious change. Only 6 female respondents said that before marriage family consent is essential and only 7 male and 12 female respondents said that they allowed gifts to peer groups before marriage. Despite religious change and commercialization, their marriage rituals and customs reveal continuity in change rather than a total break from the past.

Table 5. Customs before marriage in the Garo community

\begin{tabular}{|l|c|c|c|c|c|c|c|}
\hline \multirow{2}{*}{ Customs before marriage } & \multicolumn{2}{|c|}{ Haluaghat } & \multicolumn{2}{c|}{ Modhupur } & \multicolumn{2}{c|}{ Total } & \multirow{2}{*}{ Total } \\
\cline { 2 - 7 } & Male & Female & Male & Female & Male & Female & \\
\hline Bride price given & 0 & 0 & 0 & 0 & 0 & 0 & 0 \\
\hline Live together after elder's consent & 0 & 0 & 0 & 0 & 0 & 0 & 0 \\
\hline Family consent & 0 & 4 & 0 & 2 & 0 & 6 & 6 \\
\hline Church clearance & 8 & 10 & 12 & 14 & 20 & 24 & 44 \\
\hline Until marriage no live together & 20 & 30 & 20 & 28 & 40 & 58 & 98 \\
\hline Gifts to peer group & 5 & 7 & 2 & 5 & 7 & 12 & 19 \\
\hline Total & 33 & 51 & 34 & 49 & 67 & 100 & 167 \\
\hline
\end{tabular}

Source: Field Survey, 2009

\section{Residential pattern after marriage}

In the matrilocal Garo tradition a male marry into a female's house. The non-heiress daughters may stay in their parental home for a year or two till they establish their independent households and live separately from both the man's and woman's parents. Table 6 shows that 62 couples have built their house away from the husband's or wife's parents, 8 are staying in the bride groom's house but are independent, 13 couples are staying in the bride's house but are independent, 12 are living away from the bride groom's house but are independent and 5 said that they belong to the groom's family but live away from his parents. In some cases the groom takes his wife to his house if the girls parents do not agree to the match. Residencial pattern after marriage in the Garo Community is shown in Table 6.

Table 6. Residence after marriage in the Garo community

\begin{tabular}{|l|c|c|c|c|c|c|c|}
\hline \multicolumn{1}{|c|}{ Residencial pattern } & \multicolumn{2}{c|}{ Haluaghat } & \multicolumn{2}{c|}{ Modhupur } & \multicolumn{2}{c|}{ Total } & Total \\
\cline { 2 - 8 } & Male & Female & Male & Female & Male & Female & 5 \\
\hline Bridegroom's house & 0 & 0 & 0 & 5 & 0 & 5 \\
\hline $\begin{array}{l}\text { Start an independent family in the } \\
\text { bridegroom's house }\end{array}$ & 0 & 3 & 2 & 3 & 2 & 6 & 12 \\
\hline $\begin{array}{l}\text { Independent family away from } \\
\text { bridegroom's house }\end{array}$ & 2 & 8 & 0 & 2 & 2 & 10 & 2 \\
\hline $\begin{array}{l}\text { Independent family in } \\
\text { bride's house }\end{array}$ & 6 & 2 & 5 & 0 & 11 & 13 \\
\hline $\begin{array}{l}\text { Independent family away from } \\
\text { bride's house }\end{array}$ & 0 & 0 & 0 & 0 & 0 & 0 & 0 \\
\hline Independent family away from both & 12 & 17 & 15 & 18 & 27 & 35 & 62 \\
\hline Total & 20 & 30 & 22 & 28 & 42 & 58 & 100 \\
\hline
\end{tabular}

Source: Field Survey, 2009 


\section{Traditional Sangsharek rituals of Garo marriage}

Before conversion to Christian, the Garo people were practicing the Sangsharek rules of marriage (Khaleque, 1984). In the Garo, for marriage there was a traditional practice of 'bridegroom capturing', which has stopped now. Regarding this type of marriage, at first, the girl expressed her choice to her mother, uncle or brother. Then the girl's uncle or someone kin who follows the boy's movement and following her choice, one night some people from her clan and family members must captured the boy and bring him to the girl's house to live as a couple after the ceremonial rituals. While the people are returning with the captured man on the way they shout with joy. After the rituals of the Kamal (Head man) the people give food along with the new couple. At this event, the girl's family give two chickens for the marriage party. Kamal kills these two chickens and say 'I am sacrificing these two chickens for two of you' then he keenly observe the stomach of the chicken, if they are full with food then the Kamal declare that this couple have a prosperous life and vice versa. From that night on, the couple live together, but if the boy dislikes that girl, then he leaves the house immediately that night. Following his departure, again some young man capture and bring him to the girl's house to sleep together with the girl. This time some young people guard around the house so that the captured groom cannot escape from the house. Normally, at this stage, the captured boy does not escape. On the following day some women of the bride's family visit the boy's family with some fresh food to cook there for the boy's family. According to the Sangsharek rituals, among the Garos there was another traditional practice of marriage, which was termed as 'Thunapp'a marriage' meaning sleeping together. According to the ritual of this marriage, for making a proposal to the likings boy, the girl cooks a dish and sends it to the man of her choice by some one female relation. The girl remains in hiding but follows close behind. If the boy takes and tastes the food then it is assumed that the boy has accepted the offer and the girl comes forward and eats with him. If the boy refuses to eat, then the girl assumes that the boy has refused her proposal, but she follows where the boy sleeps, and then the girl goes to him late at night and lies down with him. If the man still refuses the girl, then he leaves the village for a few days and if he relents, he becomes her husband from that night without any ceremony.

\section{Comparative changes in marriage and related cultures between the Hilly Garos and the Plain Garos}

Comparative analysis of the marriage rituals of the Garo Adivasi community involves many factors. In recent decades, Garo people have been influenced differently by many factors such as Christianity, occupational diversification, Muslim and Hindu customs and other factors which have brought comprehensive changes in many aspects of the Garo lives, including their traditional marriage system and rituals. In some places, these changes happened in higher levels and in other places to lower degree, but all of the Garos have accepted some changes in their culture especially in marriage rituals. In both the study upazila, most of the people have been converted to Christian and share the Christian rites and rituals for establishing their marriage. There are a few people still practicing their traditional Sangsharek religion but the Garos of Haluaghat are more strict on their own traditional practices for establishing their marriage than Garos of Modhupur. The comparative changes between the two studies areas are shown in following table.

Table 7 shows that $32 \%$ and $54 \%$ respondents practice formal church marriage, $34 \%$ and $40 \%$ said more expensive, $16 \%$ and $8 \%$ follows traditional Sangsharek rituals and $6 \%$ and $16 \%$ enjoyed marrying outside in Haluaghat and Modhupur, respectively. Shorter rituals and group marriage are not practice now. Forced and child marriage is negligible. Analyzing Garos marriage rituals and comparative changes reveal that the Garos have mostly acculturated Christian rites of marriage but still there are some traditional practices in their marriage. Garos' existing marriage rituals can be mentioned as an amalgamation of the traditional and Christian traits. Christian religion, which has defused modernity and western values over the Garo society, has abruptly changed their traditional way of lives. The earlier discussions also reveal that the changes in Garos marriage rituals also invite the changes in their traditional matrilineal social system. This thing shows the interdependence of the cultural institutions of the Garo community. There might have influences of some other factors, but these types of changes are bringing greater changes in overall Garo culture. 
Table 7. Changing different marriage rituals

\begin{tabular}{|l|c|c|c|c|}
\hline \multicolumn{1}{|c|}{ Different marriage rituals } & \multicolumn{2}{c|}{ Haluaghat } & \multicolumn{2}{c|}{ Modhopur } \\
\cline { 2 - 5 } & No. & $\%$ & No. & \% \\
\hline No change & 3 & 6 & 0 & 0 \\
\hline Traditional Sangsharek rituals & 8 & 16 & 4 & 8 \\
\hline Shorter rituals & 0 & 0 & 0 & 0 \\
\hline Muslim customs introduced & 4 & 8 & 9 & 18 \\
\hline Formal Church marriage & 16 & 32 & 27 & 54 \\
\hline More expensive & 17 & 34 & 20 & 40 \\
\hline Less expensive & 5 & 10 & 2 & 4 \\
\hline Cross-Cousin marriage & 3 & 6 & 4 & 8 \\
\hline Group marriage & 0 & 0 & 0 & 0 \\
\hline Forced marriage & 2 & 4 & 0 & 0 \\
\hline Child marriage & 1 & 2 & 0 & 0 \\
\hline Marrying outside & 3 & 6 & 8 & 16 \\
\hline
\end{tabular}

Source: Field Survey, 2009

\section{Conclusion}

There are many internal and external factors responsible for Garo's cultural changes such as Christianity, formal education, modernization, occupational diversification, Bengali settlement, migration to the city for work and income, TV, radio, etc. In both upazila, there are a few people still practicing their traditional Sangsharek religion but comparatively the Garos of Haluaghat are very strict on their own traditional practices for establishing their marriage than Garos of Modhupur.

\section{References}

Ahmed, K. 2009. Changing Patterns of Marriage and Cultural System of Adivasi Garo Community. Unpublished MS Thesis submitted to the Department of Rural Sociology, Bangladesh Agricultural University, Mymensingh.

Bal, E. 2000. They ask if we eat frogs: Social boundaries Ethnic Categorization, and the Garo People of Bangladesh. Netherlands: Uitgeverij Eburon Press Limited.

Banglapedia. 2006. The National Encyclopedia of Bangladesh Edited by Prof. Sirajul Islam, Asiatic Society, Dhaka.

BBS. 2001. Statistical Year Book of Bangladesh, Bangladesh Bureau of Statistics, Statistics Division, Ministry of Planning, Government of the People's Republic of Bangladesh, Dhaka, Bangladesh.

Bleie, T. 2005. Tribal People, Nationalism and The Human Rights Challenges: The Adivasis of Bangladesh. Dhaka: The University Pres Limited.

Burling, R. 1997. The Strong Women of Modhupur, Dhaka: University Press Limited.

Chowdhury, K.A.N. 2007. Residence, Gender and Power in the Garo Society of Bangladesh, Dhaka: University of Dhaka. Doctoral Thesis.

Khaleque, K. 1984. Social Change Among the Garos: A Study of a Plain Villages of Bangladesh. Canberra: Department of Prehistory and Anthropology, Australian National University, Australia (Master Thesis).

Partha, P. 2003. Biodiversity of Modhupur Tract. Bangladesh Resource Center for Indigenous knowledge (BARCIK), Dhaka.

Playfair, M. 1998. The Garos. Delhi: D.K. Fine Art Press Limited. 